\title{
La psicología del arte analizada desde la melancolía en la obra
}

\section{"El laberinto del minotauro"}

\author{
The psychology of art analyzed from melancholy in the work "The minotaur's labyrinth" \\ A psicologia da arte analisada a partir da melancolia na obra "O labirinto do minotauro"
}

\section{ARTÍCULO GENERAL}

Raul Demetrio Arredondo Gamis rarredondo@unsa.edu.pe

https://orcid.org/0000-0001-5851-976X

Universidad Nacional de San Agustín de Arequipa. Arequipa - Perú

\section{Slink Victor Dueñas Silva}

sduenass@unsa.edu.pe

https://orcid.org/0000-0002-5552-8449

Universidad Nacional de San Agustín de Arequipa,

Arequipa - Perú

Recibido 05 de Febrero 2021 | Arbitrado y aceptado 19 de Abril 2021 | Publicado 28 de Julio 2021

\section{Resumen}

La melancolía en "El laberinto del minotauro" de Ricardo Córdova Farfán, es una investigación reflexiva $\mathrm{y}$ teorética inmerso en el campo de la estética freudiana. Este artículo se fundamentó bajo la premisa de que las estructuras del inconsciente del psiquismo de pintor tenían una relación directa con su obra, puesto que la creación artística no puede disociarse del inconsciente del creador, sino es un reflejo fiel de su percepción, de su mundo interior y de su imaginación. Así, el propósito del artículo fue analizar a nivel del psicoanálisis los presupuestos psicológicos en la obra "El laberinto del minotauro" de Ricardo Córdova Farfán, incidiendo en la teoría de la melancolía. Asimismo, se tuvo como objetivo específico Analizar a nivel de la psicología del arte y la estética algunas obras de Ricardo Córdova donde se observa la presencia del temperamento melancólico. Para la comprensión, el análisis y la interpretación de las obras de Córdova, se utilizó la hermenéutica de los símbolos, por ser el método más adecuado para esta clase de discurso. Se concluyó que "El laberinto del minotauro" de Ricardo Córdova; es una alegoría a la melancolía y a la imposibilidad de encontrar la libertad plena. El pintor recrea el mito griego del minotauro, pero desde una visión del arte moderno. Bajo la luz de la teoría psicoanalítica los personajes que rodean a Asterión, no sólo reflejan ciertos estados de melancolía como producto del desencanto con la realidad, sino reflejan sobre todo algunas estructuras oscuras del inconsciente del ser humano. Palabras clave: El laberinto del minotauro, melancolía, inconsciente, arte, psicología.

\section{Abstract}

Melancholy in "The Minotaur's Labyrinth" by Ricardo Córdova Farfán is a reflective and theoretical investigation immersed in the field of Freudian aesthetics. This article was based on the premise that the unconscious structures of the painter's psyche had a direct relationship with his work, since artistic creation cannot be dissociated from the creator's unconscious, but is a faithful reflection of his perception, of his world. interior and your imagination. Thus, the purpose of the article was to analyze at the level of psychoanalysis the psychological presuppositions in the work "El laberinto del minotauro" by Ricardo Córdova Farfán, focusing on the theory of melancholy. Likewise, the specific objective was to analyze at the level of the psychology of art and aesthetics some works by Ricardo Córdova where the presence of the melancholic temperament is observed. For the understanding, analysis and interpretation of Córdova's works, the hermeneutics of symbols was used, as it is the most appropriate method for this kind of discourse. It was concluded that "El laberinto del minotauro" by Ricardo Córdova; It is an allegory of melancholy and the impossibility of finding full freedom. The painter recreates the Greek myth of the minotaur, but from a modern art point of view. Under the light of psychoanalytic theory, the characters that surround Asterión not only reflect certain states of melancholy as a result of disenchantment with reality, but above all they reflect some dark structures of the human being's unconscious.

Keywords: The minotaur's labyrinth, melancholy, unconscious, art, psychology.

\section{Resumo}

Melancolia em "O labirinto do Minotauro" de Ricardo Córdova Farfán é uma investigação reflexiva e teórica imersa no campo da estética freudiana. Este artigo partiu da premissa de que as estruturas inconscientes do psiquismo do pintor tinham uma relação direta com a sua obra uma vez que a criação artística não pode ser dissociada do inconsciente do criador, mas é um reflexo fiel da sua percepção, do seu mundo. Interior e do seu imaginação. Assim, o objetivo do artigo foi analisar no plano da psicanálise os pressupostos psicológicos da obra "El laberinto del minotauro" de Ricardo Córdova Farfán, enfocando a teoria da melancolia. Do mesmo modo, o objetivo específico foi analisar ao nível da psicologia da arte e da estética algumas obras de Ricardo Córdova onde se observa a presença do temperamento melancólico. Para a compreensão, análise e interpretação da obra de Córdova, utilizou-se a hermenêutica dos símbolos, por ser o método mais adequado para este tipo de discurso. Concluiu-se que "El laberinto del minotauro" de Ricardo Córdova; É uma alegoria da melancolia e da impossibilidade de encontrar a liberdade plena. O pintor recria o mito grego do minotauro, mas do ponto de vista da arte moderna. À luz da teoria psicanalítica, os personagens que circundam Asterión não só refletem certos estados de melancolia pelo desencanto com a realidade, mas sobretudo refletem algumas estruturas sombrias do inconsciente do ser humano. Palavras-chave: $\mathrm{O}$ labirinto do minotauro, melancolia, inconsciente, arte, psicologia. 
Introducción

Cuando una persona asiste a un vernissage, es decir, a una exposición de arte y ve las creaciones de los artistas, en un inicio no comprende su verdadero significado, y es tal vez, porque se desconocen ciertas disciplinas como la psicología del arte, la filosofía del arte, la estética, la antropología del arte, la semiótica, etc. Estas disciplinas podrían ayudar a interpretar una determinada obra de arte desde el punto de vista del contexto sociohistórico-cultural y psicológico, en el cual fue creado la obra.

En el contexto de la ciudad de Arequipa, hay pocos análisis de investigación sobre la pintura arequipeña del siglo XXI, a un nivel interdisciplinario e intertextual; frente a esta problemática se propone en este artículo realizar tentativamente un modelo de análisis desde el punto de vista de la psicología del arte, incidiendo en la teoría de la melancolía en la obra "El laberinto del minotauro".

Para esta investigación hermenéutica, se eligió la obra mencionada previamente del artista Ricardo Córdova Farfán, en la medida que es el ideal para esta clase de elucubraciones y porque el pintor es considerado por la crítica nacional e internacional como uno de los más importantes y representativos de la pintura arequipeña del siglo XXI.

Sobre su obra, "El laberinto del minotauro", esta obra es una reminiscencia del mito griego, pero bajo una visión del arte moderno donde aparece la melancolía personificada en Asterión quien se halla solitario, letárgico y triste en medio del laberinto. Igualmente, este mito está rodeado de otros personajes como: Minos, Teseo, Pasífae, Ariadna y Dédalo quienes también están cargados de una historia trágica y una gran expresividad melancólica.

Cabe mencionar que, para el análisis e interpretación de la obra de Ricardo Córdova, desde la visión de la melancolía, el artículo se apoya en el psicoanálisis de Freud, en la psicología del arte de Vygostsky y en la estética. Así, para el análisis e interpretación hermenéutica de la obra de Córdova, desde la mirada de la melancolía o síntoma de la tristeza; se pudo acercarse a la misma a través de categorías de la estructura de la psique Freudiana como: la sublimación, la transferencia, el estudio del inconsciente, el tratado de la neurosis obsesiva y la teoría de la melancolía. Fue el propio Sigmund Freud en su tratado "Duelo y melancolía" quien nos da algunas pautas sobre este tema: 
La melancolía se singulariza en lo anímico por una desazón profundamente dolida, una cancelación del interés por el mundo exterior, la pérdida de la capacidad de amar, la inhibición de toda productividad y de una rebaja en el sentimiento del sí que se exterioriza en autoreproches y autodenigraciones y se extrema hasta una delirante expectativa de castigo (Freud, 1996, P.3477).

Tanto lo consciente cómo lo inconsciente dado su naturaleza abstracta, no han podido ser definidos de manera clara ni estudiadas a un nivel empírico y observacionalmente, sin embargo, el neurólogo Adam Zeman define la consciencia como:

El estado pleno de autoconocimiento, la capacidad de percibir, interactuar y de comunicarnos con el entorno y con otros individuos de la manera integrada que dicho estado de despierto implica (Quevedo, 2018, P. 16).

Haciendo una inferencia del anterior concepto sobre la consciencia de Adán Zeman, se puede sintetizar que la consciencia es tener conocimiento pleno de nosotros mismos y de nuestro contexto social en el cual nosotros estamos inmersos, aunque este estado de alerta, puede ser alterado a nivel del lenguaje, el pensamiento, la memoria y las emociones por ciertas patologías a nivel neurológico como la psicosis, la esquizofrenia, la depresión, los trastornos obsesivo-compulsivo y la melancolía.

Por debajo del umbral de la consciencia está lo inconsciente, que puede describirse como aquella zona subliminal o subconsciente que no puede controlarla la persona de manera voluntaria a nivel de la razón. Dentro de la estructura psíquica tripartita en la teoría del psicoanálisis, es en esta región profunda del inconsciente donde residen los traumas y las situaciones conflictivas del ser humano como las neurosis y las histerias.

Una obra de arte como "El laberinto del minotauro" de Córdova, no sólo tiene un sentido lineal de significación a nivel formal, como es la composición y sus diferentes elementos como: el color, la luz, el peso visual, etc. Sino que esta obra tiene un sentido latente, un sentido oculto, cuyo contenido traspasa lo explícito, es decir, que este texto o discurso pictórico refleja una significación escondida.

Por eso, el objetivo general del presente artículo fue analizar a nivel del psicoanálisis los presupuestos psicológicos en la obra "El laberinto del minotauro" de Ricardo Córdova Farfán, incidiendo en la teoría de la melancolía. Asimismo, se tuvo 
como objetivo específico Analizar a nivel de la psicología del arte y la estética algunas obras de Ricardo Córdova donde se observa la presencia del temperamento melancólico.

\section{Metodología}

El estudio fue cualitativo y puede ubicarse según la gnoseología dentro del segundo nivel del conocimiento, es decir, el conocimiento pre-científico. Se indica que formó parte de este conocimiento, en la medida que su finalidad no fue demostrar en el campo del positivismo reduccionista resultados a un nivel matemático o estadístico, es decir, no se midieron indicadores, no obstante, el conocimiento que se ha obtenido en el análisis hermenéutico de la pintura "El laberinto del minotauro", objeto de análisis en la presente, debe comprenderse como un conocimiento de divulgación; producto de un estudio crítico, sistemático y bibliográfico. Es crítico porque surge de un proceso reflexivo apoyado en teorías psicológicas como el psicoanálisis y la filosofía del arte.

Asimismo, aparte de usar algunos elementos de la investigación cualitativa, también se tomaron en consideración algunas estrategias metodológicas de la investigación exploratoria y descriptiva, pero sobre todo el estudio se apoyó en el método y la técnica de interpretación hermenéutica para analizar la complejidad del lenguaje pictórico en la obra de Córdova.

La hermenéutica como teoría filosófica y método en la comprensión e interpretación de textos se ha utilizado en todos los campos del conocimiento humano, excepto en las artes plásticas, empero, se debe también tener en cuenta que una pintura también es un texto, un discurso, un lenguaje que puede ser interpretado a un nivel hermenéutico de los símbolos. Es por esta razón que en la presente se hizo uso de la hermenéutica equivocista en el análisis de la obra de Ricardo Córdova mencionada previamente.

\section{Resultados y discusión}

La filosofía, como saber teorético sobre la realidad, para algunos exégetas no nació con el florecimiento de la cultura clásica griega, sino que los problemas sobre el ser, la existencia y el valor de la vida ya fueron tratados en gran profundidad en los libros sagrados como: El Ramayana, el Majabharata, el Tao Te ching y el libro de los muertos, provenientes de las culturas, hindú, China y Egipcia, sin embargo, es en Grecia en donde aparece el término "logos" como principio, conocimiento, ciencia y explicación racional sobre los aspectos generales del ser y del universo. Es así que los griegos con el 
surgimiento de la filosofía se aislaron del pensamiento mítico, mágico y religioso de las culturas precedentes.

Dentro de las etapas de la historia de la filosofía es importante destacar algunas características para ubicar el racionalismo en la cultura occidental. En el período clásico la filosofía se enfocaba sobre todo en la cosmología. En la edad media que duró aproximadamente un milenio la ciencia queda estancada porque el centro y explicación ontológica de todo cuanto existe se da a un nivel teológico, pero la fase más importante y determinante en la construcción de la sociedad y del pensamiento del siglo XX y XXI es la etapa contemporánea, pues en esta época se establece la razón y la ciencia como modelo de conocimiento.

En la historia de las doctrinas filosóficas hay pocos hombres que han sido elegidos por la naturaleza para cambiar el pensamiento de la humanidad a un nivel ontológico, gnoseológico y a un nivel axiológico. Uno de estos visionarios es el filósofo René Descartes, pues a través de su discurso, la filosofía se separa de la teología; dando paso así a la autonomía de la filosofía como modelo de ciencia e investigación a nivel empírico y nacional. Uno de los estudiosos más agudos de la obra de Descartes es Jaume Xiol y el afirma:

Ciertamente, con Descartes y la nueva interpretación de la realidad y del conocimiento que necesitaba la ciencia moderna, comenzó un nuevo camino en el mundo de las ideas, hasta el punto de representar una auténtica fractura con relación a toda la filosofía anterior. A partir de sus tesis y planteamientos, y también confrontarlos, todos los filósofos posteriores tuvieron que posicionarse. Se sucedieron las problemáticas y las discusiones, cuyas evoluciones dieron lugar a las distintas familias filosóficas con las que, convencionalmente, las historias del pensamiento han intentado ordenar su desbordante historia. (Xiol, 2015, P. 11).

Con la luz de las elucubraciones mentales de los filósofos: Descartes, Spinoza Leibniz, el racionalismo como disciplina filosófica llegó a la cumbre del conocimiento gnoseológico en el siglo XVI. Posteriormente y en oposición al racionalismo surgió el empirismo encabezado por los filósofos Locke, Berkeley y Hume, estos pensadores 
sostienen que el conocimiento es producto de la percepción de los sentidos y de las impresiones.

Antes de entrar en el análisis profundo de los personajes de la obra "El laberinto del minotauro" de Ricardo Córdova, pero desde una perspectiva psicoanalítica; en esta parte de la investigación hermenéutica, nos interesa conocer algunas características gnoseológicas del racionalismo cartesiano. Los racionalistas sostienen que nuestros conocimientos acerca de la realidad proceden de la razón, asimismo el conocimiento es connatural al ser humano a semejanza del innatismo platónico. Para la teoría cartesiana el asiento básico del conocimiento no son los sentidos como creen los empiristas sino es el entendimiento como facultad única y exclusiva del hombre.

En el racionalismo cartesiano es importante destacar que la idea como constructo mental representa a la realidad y de allí su fórmula "Cogito ergo sum" como criterio de verdad. También debemos destacar que uno de los aportes más grandes en el campo de la epistemología es la duda metódica cartesiana y sus reglas como: Análisis, síntesis y la regla de las numeraciones, reglas que van a determinar y fijar como estudiar la realidad de manera objetiva y evidente, para de esta manera alejarnos del irracionalismo y la incertidumbre. Sobre los pilares del racionalismo y del empirismo se ha construido la cultura occidental y se ha reafirmado y consolidado, el positivismo de Auguste Comte.

En 1960 aparece un libro extraordinario del estadounidense Thomas Khun denominado "Estructuras de las revoluciones científicas". A partir de la publicación de esta obra, hay un cambio radical en la orientación filosófica y sociológica del conocimiento. Khun sostiene que toda teoría tiene una estructura dinámica y que todos los paradigmas que habían dado solución a una problemática en un periodo determinado y en un contexto histórico - social, estas teorías entraban en crisis para dar lugar a otra teoría. Siguiendo esta teoría, el modelo del racionalismo cartesiano y el empirismo lockeano se pone en cuestionamiento con la aparición de la filosofía psicoanalítica fundada por Sigmund Freud; aunque, esta tendencia psicológica ha sido vilipendiada en sumo grado por la crítica especializada, sobre todo por la psiquiatría, pero también debemos reconocer que ha tenido grandes aciertos en el campo terapéutico y en las humanidades.

En el siglo XXI, la teoría psicoanalítica no solamente es utilizada en el campo de la psicología clínica como terapia, sino también entra en los análisis de los discursos 
literarios y en la psicología del arte. En el campo de la literatura ha aparecido una nueva tendencia denominada psicocrítica, un método que consiste en analizar la obra a partir del discurso literario y no de la biografía del autor. El creador de la psicocrítica y máximo exponente Charles Mauron, establece que la psicocrítica tiene como característica fundamental el uso de las teorías freudianas en el análisis literario. El ejemplo más conocido de esta teoría literaria, es el estudio de la tragedia "Edipo rey" del dramaturgo Sófocles, en donde se afirma de manera categórica el deseo del hijo de poseer a su madre y matar a su padre, pues recordemos que Edipo mata a su padre Layo rey de Tebas y se casa con su madre la reina Yocasta y de ella tiene cuatro hijos: Antígona, Ismena, Polinice y Eteocles.

En el psicoanálisis las estructuras de la psique propuestas por Sigmund Freu, son determinantes para el análisis de la obra creada como del creador. Esta explicación es evidente en el surrealismo en donde se evidencia la personalidad inconsciente del artista y su efecto catártico o descarga pulsional expresado en la obra de arte. La diferencia de la psicología del arte y la psicocrítica, radica, en que la psicología del arte toma como base el contexto social, la personalidad del artista y la simbología del lenguaje artístico; en cambio la psicocrítica sólo analiza el discurso literario.

El modelo psicoanalítico freudiano se valió de la literatura, la escultura y la pintura como metáforas para poder explicar algunas estructuras de la psique en relación con el complejo de Edipo, la sexualidad, la libido y la naturaleza pulsional del artista. Son prueba de ello "un recuerdo infantil de Leonardo Da Vinci", el "Moisés"de Miguel Àngel y “Dostoivski y el parricidio”.En la práxis, el modelo psicoanalítico freudiano, ha sido llevado con sutileza y una aplicación extraordinaria al campo de la pintura; por el crítico de arte Daniel Schneider con su obra "El psicoanalista y el artista". En esta obra, el curador analiza profundamente la captación del subconsciente en el pintor francés Eugéne Delacroix, el simbolismo en Marc Chagall y los conflictos sociodramáticos en Pablo Picasso.

Para la escuela psicoanalítica en el centro de toda narrativa mítica se oculta un aspecto de la realidad, pues a través del mito como segunda esfera del conocimiento, no sólo podemos explicar el origen del universo; el surgimiento de una cultura, sino también podemos explicar los aspectos inconscientes de la mente. Hay tratados interminables y análisis extraordinarios como del mitólogo Robert Graves en relación con "El laberinto 
del minotauro" sin embargo, nuestro estudio en esta parte de la investigación, se centra en la misma naturaleza del minotauro, pero bajo la luz de la teoría psicoanalítica incidiendo en el inconsciente y en el estado melancólico.

Según la historia de la psicología, esta disciplina formaba parte de la filosofía, fue Platón el primer filósofo en hablar de la inmortalidad del alma mediante mitos y alegorías. En el diálogo llamado "Fedro" Platón sostiene que el alma de las personas posee una fuerza oscura que entorpece a la razón personificado por el caballo negro. Esta fuerza oscura e indomable en la teoría psicoanalítica es análogo al "ello" al "inconsciente".

Hemos distinguido en cada alma tres partes diferentes por medio de la alegoría de los corceles y del cochero. Sigamos, pues, con la misma figura. Uno de los corceles, decíamos es de buena raza, el otro es vicioso. Pero ¿de dónde nacen la excelencia del uno y el vicio del otro? Esto es lo que hemos dicho y lo que vamos a explicar ahora. El primero tiene soberbia planta, formas regulares y bien desenvueltas, cabeza erguida y acarnerada; es blanco con ojos negros; ama la gloria con sabio comedimiento; tiene pasión por el verdadero honor, obedece, sin que se le castigue, a las exhortaciones y a la voz del cochero. El segundo tiene los miembros contrahechos, toscos, desaplomados, la cabeza gruesa y aplastada, el cuello corto; es negro, y sus ojos verdes y ensangrentados; no respira sino furor y vanidad; sus oídos velludos están sordos a los gritos del cochero, y con dificultad obedece a la espuela y el látigo (Platón, 2005, P. 519).

En el psicoanálisis de Freud es importante señalar la existencia de una parte instintiva del yo, y que para Platón como vemos en el anterior o fragmento está representado por la fuerza descomunal del caballo negro. Sigmun Freud a pesar de haberse graduado de doctor en la facultad de medicina de la universidad de Viena en 1873, sin embargo, sus teorías sobre la estructura de la psique humana no son de naturaleza anatómica, por lo tanto, no están relacionados con determinadas regiones del cerebro a un nivel neurológico. La teoría freudiana se caracteriza porque hace un viaje a las profundidades de la mente a un nivel metafórico, estableciendo tres regiones, el inconsciente, el preconsciente y el consciente.

Para el análisis de la obra "El laberinto del minotauro" de Ricardo Córdova, desde la perspectiva del psicoanálisis, partimos de la interrogante ¿Qué relación existe entre el 
mito, la melancolía y la sublimación como un factor clave de la creatividad? En los anales de la historia de la mitología cretense encontramos la historia terrible de la unión de un toro blanco (engendrado por el Dios Poseidón) y la reina Pasífae de cuyas entrañas nació un monstruo con cuerpo de hombre y cabeza de toro.

Al levantar las ropas de la reina, un gesto de alarma turbó el rostro de la matrona. El vientre de la parturienta hervía como un estanque de agua sulfurosa. Algo no iba bien. La mujer dispuso sus instrumentos y se preparó para un parto difícil.

Cuando el nuevo ser vio la luz, las dos mujeres retrocedieron aterrorizadas. Del útero de la reina emergió un ser monstruoso. Su cuerpo de hombre estaba coronado por una cabeza de toro; cuernos dorados, belfos carnosos, ojos bovinos. Agitaba sus miembros intentando incorporarse, pero no podía fijar sus pies con seguridad. El monstruo cayó al suelo y abrió sus fauces emitiendo un bramido agudo y mostrando unos dientes impropios de un bóvido. Pasífae, desfallecida por el esfuerzo, fue conducida un lecho en compañía de su hijo. Un extraño olor, parecido al de un establo, inundaba la habitación cuando Minos entro para conocer a su nuevo hijo. (Souvirón, 2017, P. 41).

Figura 1. Pasifae y el minotauro (119)

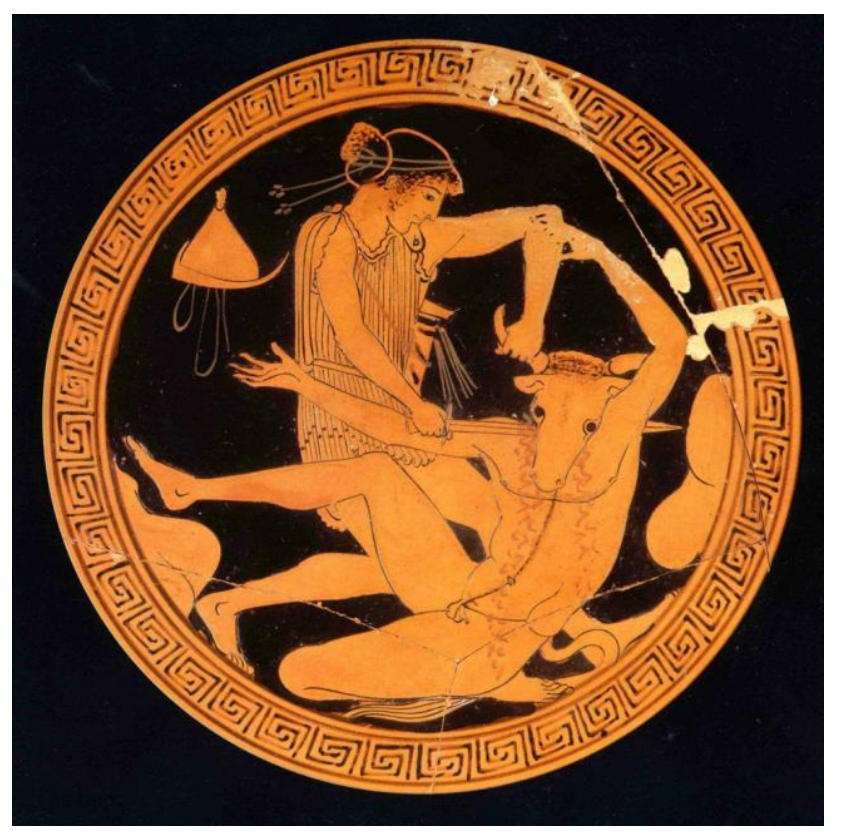


En la anterior ilustración observamos a una criatura híbrida de naturaleza bestial, con cuerpo de hombre y cabeza de toro, quien se halla sentado plácidamente sobre el peplo de la reina Pasífae. En la configuración física del ser humano es esencial la cabeza, porque es la base del cerebro y el cerebro es el asiento de la razón, la conciencia y el pensamiento. El minotauro, cuyo nombre es Asterio o Asterión carece de la cabeza humana. El término de "carencia" en el psicoanálisis tiene una connotación muy diferente al significado lineal y denotativo del lenguaje; pues no sólo expresa falta o ausencia de algo, sino que adquiere la connotación de privación, por lo tanto, hay una relación directa de causa efecto, que lo podemos tomar como privado de la razón, privado de juicio. Esta es nuestra primera aproximación en el análisis del minotauro bajo el enfoque psicoanalítico.

Con el paso incesante de los años, el crecimiento económico de creta bajo el reinado del monarca Minos llegó a la cúspide. El esplendor o la edad de oro de los cretenses se vio reflejado en el dominio comercial de todo el mediterráneo, sin embargo, no todo es bienestar para la casa real, porque la reina Pasífae y el rey Minos sienten vergüenza por Asterión; que, con el paso del tiempo, sus impulsos de lo primitivo y salvaje están dispuestos a estallar. Por este motivo es arrojado a las entrañas oscuras de un laberinto construido por el artífice Dédalo.

Algunas noches, empero, cuando el silencio se cernía sobre la tierra de Cnosos, un lejano gemido, el fleco desgajado de un bramido distante, se oía desde las estancias reales. Era apenas perceptible, y nadie parecía reparar en su existencia. Sin embargo, al oírlo Pasifae se revolvía en su lecho, se tapaba los oídos con las manos e intentaba conciliar el sueño y alejar de sí el horrible remordimiento. Cuando el sueño la vencía, de nuevo el quejido penetraba como un aguijón en su cabeza, recordándole el infausto coito y, a la vez, el indecible placer; el ingrato remordimiento y la dulce sensación de agotamiento que invadieron su cuerpo aquella noche (Souvirón, 2017, P. 49).

El encierro del minotauro en los oscuros pasadizos del laberinto, creemos que se deben a tres razones: la primera radica en evitar la violencia de los instintos primitivos de Asterión sobre los habitantes de Cnosos. La segunda razón por el cual es enviado el minotauro al laberinto sombrío, es que el ideal de los cretenses en lo referente al arte y la 
belleza estaba ligado al equilibrio, a la armonía, a lo sublime a lo delicado en contraste con lo grotesco y lo monstruoso que representaba el minotauro.

Teseo se había escondido debajo de la paja sucia conteniendo las náuseas, respirando despacio, decidido a dar el primer golpe. Desde allí lo veía perfectamente: brazos de acero, piernas de mármol, cerdas hirsutas recorriendo su cuerpo, costras sanguinolentas infestadas de parásitos latiendo sobre sangre seca. Dos pitones afilados y ennegrecidos coronaban su frente, belfos enormes y húmedos, fauces semiabiertas, dientes biliosos y ojos grandes, enrojecidos, de pupilas dilatadas por la obscuridad, una mirada que transmitía resentimiento y tristeza. (Souvirón, 2017, P. 84).

La tercera causa por el cual es arrastrado Asterión a vivir en la lóbrega mansión es para ocultar las desviaciones o perversidades de la reina Pasífae, aberraciones que se ven ante la sociedad cretenses como antinatural en el plano moral y biológico; es decir para ocultar la vergüenza, terminó, que en el mito adquiere una dimensión fenomenológica de malestar, un terror de ser y hasta una preocupación existencial.

En el psicoanálisis es importante comprender dentro de la estructura tripartita de la Psique humana el "inconsciente". Asimismo, es muy difícil definir de manera certera y completa esta noción, puesto que ha pasado por diferentes disciplinas como la filosofía, la psiquiatría, la neurología y la antropología, no obstante, hemos tratado de aproximarnos a algunas características del "inconsciente" que nos han ayudado en el análisis de la pintura "El laberinto del minotauro" de Ricardo Córdova. La noción del "inconsciente" en la filosofía nihilista de Arthur Schopenhauer aparece como una carencia de voluntad, como una carencia de control en relación con un cogito consciente. Lo que diferencia al homo Sapiens del animal, no sólo es la voluntad, el control y el lenguaje, sino es sobre todo el conocimiento reflexivo y criticó sobre la realidad.

Desde el punto de vista del psicoanálisis, el minotauro al ser un animal irracional, no existe en él una censura que haga de control de los deseos del inconsciente; no hay en él la instancia prohibitiva que habla de reprobación de lo primitivo y salvaje. En el minotauro sólo prevalecen las pulsiones de agresión cuyo único fin es la destrucción y la pulsión de autoconservación cuyo objetivo solamente es la alimentación. Por estos motivos, cuando el príncipe Teseo entra en el laberinto de las sombras encuentra en cada pasadizo sólo huesos y sangre: 
Un escalofrío encogió su cuerpo mientras empezaba a sudar; el ungüento de Ariadna surgía de sus poros, notaba la humedad en sus miembros. Se despojó de la túnica con cuidado, con sus ojos cada vez más hechos a la escasa luz, creyó distinguir sobre el suelo más huesos, hierba sucia, seca, forraje manchado de sangre. Advirtió que se encontraba en una estancia algo más ancha, un lugar de pesadilla. Por un momento imagino el destino del monstruo, su vida entre las tinieblas de aquella tumba, su sentencia a una noche perpetua, como si estuviera en vida condenado al Hades. (Souvirón, 2017, P. 81).

De la inmensa producción artística de Ricardo Córdova "El laberinto del minotauro" es el único óleo en donde el personaje central se remonta a la mitología griega. Si observamos detenidamente esta pintura podemos ver intrincados laberintos que el artista ha logrado a través de trazos y efectos de luz, en medio del laberinto está el minotauro pero desprovisto de su ferocidad; su rostro lánguido y negruzco apenas se observa por la obscuridad del laberinto, sus ojos están dirigidos hacia abajo como señala de humillación y sufrimiento, su respiración es acelerada por la incertidumbre y la autonegación. Al observar esta obra podemos sentir sobre la superficie de nuestra piel como recorre el silencio la desolación y la melancolía.

Figura 2. Ricardo Córdova - El laberinto del minotauro (120)
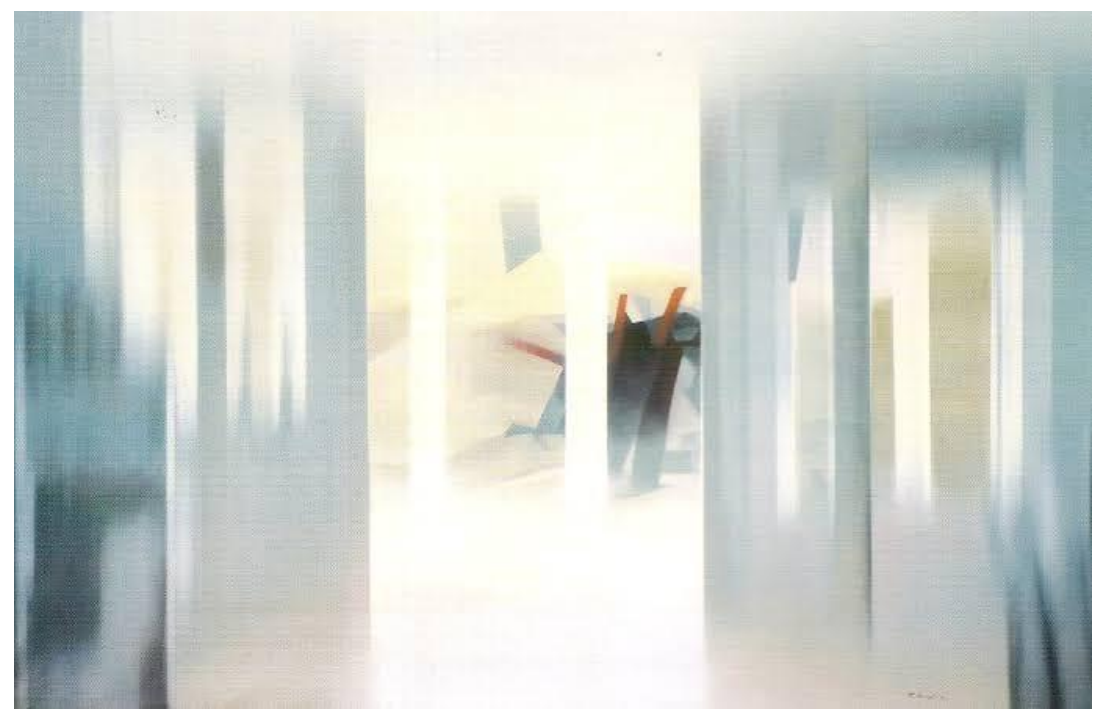

Nota. Óleo sobre lienzo $2010-125 \times 200 \mathrm{~cm}$

El significado de la melancolía desde sus orígenes ha estado ligado

inn Ricardo Córdova ina, a la tristeza, a la angustia y a los cambios de hu 
causados por la bilis negra. En la teoría psicoanalítica la melancolía está relacionado con la neurosis. El minotauro ha sido negado por su madre Pasifae, es decir, hay una falta una ausencia de afecto familiar, por lo tanto, hay una neurosis de abandono. Esta falta de amor y afecto llega a ser expresado no sólo en la melancolía, si no en la violencia física, por este motivo el minotauro devora hombres. Asimismo, en el minotauro encontramos una neurosis de destino, pero un destino que sólo produce una serie de encadenamientos funestos y desagradables.

El tiempo había hecho su trabajo. Y el laberinto también. Encerrado en aquellos lóbregos sótanos cuya salida sólo podía encontrar Dédalo, Asterión, pues así habían llamado al monstruo, había desaparecido casi por completo de la vida de Minos y Pasifae. Los reyes sabían que aquel nombre que habían utilizado para enmascarar el dolor del presente con el recuerdo de aquel amado rey del pasado, no perduraría, pues nadie lo llamaba así, sino Minotauro, según había anticipado Poseidón. (Souvirón, 2017, P. 48).

El mito del laberinto ha sido objeto de atención y estudio por diferentes pintores como F. Watts, Edouard Charse, Paul Klee y la serie de la Tauromaquia de Pablo Picasso. Pero es en la obra de Ricardo Córdova en donde el minotauro aparece casi humanizado, postrado en su sufrimiento, postrado en su desesperanza; abatido en la melancolía por la imposibilidad de encontrar la libertad. Esta idea de melancolía puede ser extendido al umbral del subconsciente del creador Ricardo Córdova, puesto que las emociones y los sentimientos del pintor no son ajenos a lo creado.

En la teoría freudiana es interesante la categoría de la sublimación. Desde el punto de vista del psicoanálisis entendemos por sublimación, al desplazamiento de ciertas pulsiones del inconsciente al arte, es decir, que la creatividad artística tiene una relación directa con el inconsciente. Si desde el punto de vista de la sublimación hay una estrecha relación entre el arte, el artista y la melancolía; podemos inferir de manera objetiva y certera, que los mecanismos que emplea el pintor Ricardo Córdova para la estructuración perfecta del discurso artístico, no sólo están en el conocimiento perfecto de la técnica de la pintura, sino también corresponden al mundo psíquico del artista y al poder de transferencia que posee Córdova para concretizar de manera inteligible y estética sus estados de ánimo y su melancolía, por lo tanto, el minotauro podría representar también el lado oscuro de su ser. 
Figura 3. Ícaro, Dédalo y Pasifae - Arte pompeyano (121)

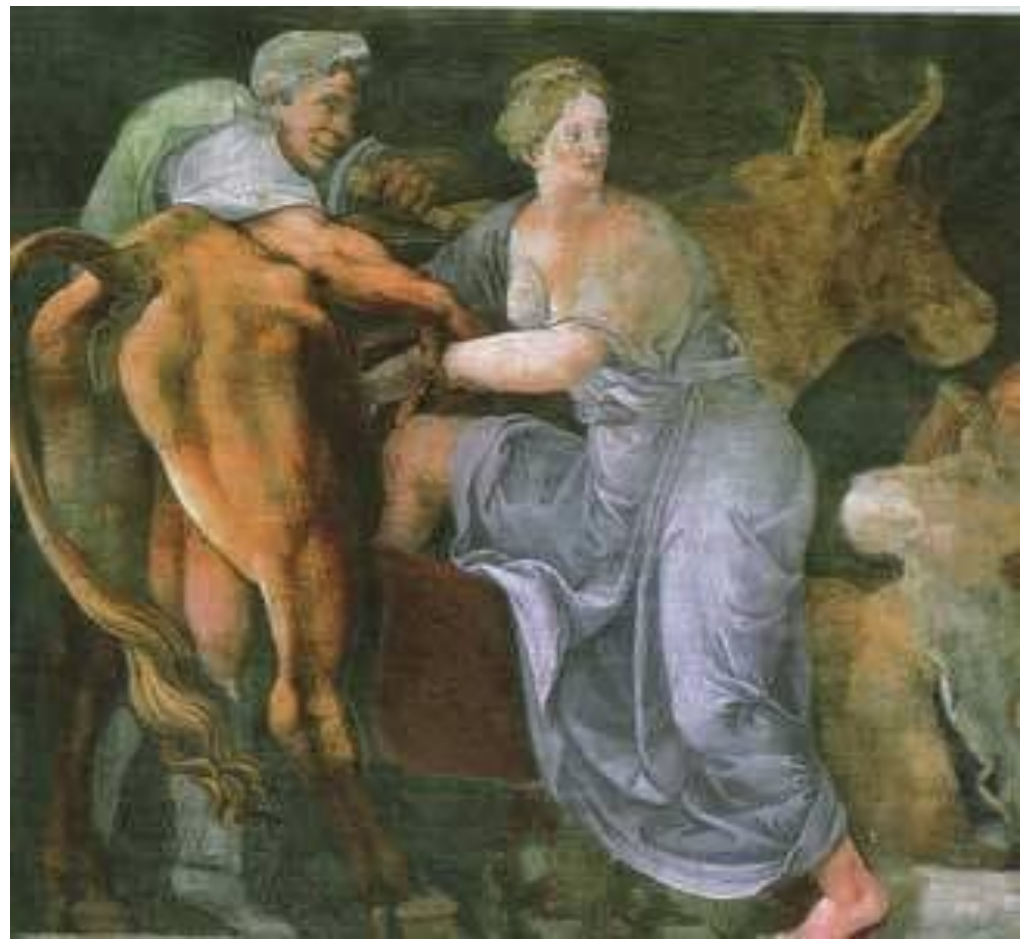

Uno de los personajes más controvertidos y poco estudiado dentro del mito del minotauro es la reina Pasífae, hija del Dios Helios y la ninfa marina creta, hermana de la maga y hechicera Circe y Eetes rey de la cólquida. Pasífae también era conocida como Perseis (la que brilla para todos). Pasifae contrajo matrimonio con el rey Minos, monarca del trono de creta, de quien tuvo seis hijos: Acacálide, Ariadna, Androgeo, Catreo, Glauco y Fedra. Según las crónicas de Apolodoro Pasífae no solamente tuvo hijos para el rey Minos, sino también para Hermes e inclusive para Zeus. Lo polémico y controversial en la vida de la reina de Creta, está en haber engendrado al minotauro como producto de su deseo sexual incontrolable por el magnífico toro blanco, regalo del Dios Poseidón.

De pronto, algo la detuvo, la mano de un gigante que aferraba sus hombros y le impedía moverse. Volvió a sentirse inflamada por el deseo brutal, por la agitación del toro. Se rindió definitivamente y se lanzó hacia la grupa en el momento en que el miembro penetraba en el interior de la máquina. Lo veía agitarse, latir, golpear, oía sus mugidos, sus golpes, que acompañaban sus gritos, mientras que la vaca temblaba de modo que parecía que estuviera a punto de derrumbarse. (Souvirón, 2017, P. 38).

Uno de los aportes más grandes de la cultura griega a la humanidad a parte de la filosofía, la arquitectura, la escultura es su mitología, que hasta el siglo XXI sigue 
fascinando a historiadores, antropólogos, psicólogos y sobre todo a los literarios. Los griegos en su alarde por la fantasía poblaron el cielo, la tierra y el mundo subterráneo, de titanes, dioses, semidioses y héroes. La característica principal de estas deidades es que estaban magnificadas, idealizadas, no obstante, tenían las mismas virtudes y defectos que las criaturas humanas.

En el mito griego, los hijos más conocidos de Saturno; Señor del universo, y la diosa Rea son: El poderoso Olímpico Zeus, quien se encarga del cielo constelado de estrellas; el inmenso Hades quien se encarga de gobernar la morada de las sombras y Poseidón que ganó el dominio de los mares. Para nuestro objetivo, en esta investigación resaltamos la presencia del Dios Poseidón, de quien los vates dicen:

Ofrezco las primicias de mi canto a Poseidón, gran dios que sacude la tierra y la vasta superficie de los mares. Hélice y Egas de vastas playas están entre tus dominios. Doble es el honor, estremecedor de continentes, por el que los hombres te rinden homenaje: el de domador de caballos y el Salvador de sus navíos. ¡Salve Poseidón, dios la negra cabellera! Que los que están en el mar gocen de tu benevolencia y tú socorro. (Ferraté, 1968, P. 91).

Poseidón el dios de las aguas y las tempestades no estaba exento de las pasiones humanas. Poseidón, como principio húmedo, era noble en sumo grado, porque al unirse con la diosa Demeter (El suelo fecundo) hacían posible la vida, sin embargo, en el dios marítimo también prevalecía la cólera y la melancolía, pues según el mito Poseidón llegó a matar a sus seis hijos arrojándolos en las entrañas oscuras de la tierra.

En la leyenda del minotauro, Poseidón, también conocido en el mundo romano con el nombre de Neptuno, aparece como un dios vengativo. A la muerte del rey de Creta, Minos hijo de Zeus y de Europa asume el gobierno de Cnosos con la ayuda del rey de los mares, Poseidón hace surgir del mar espumoso un magnífico toro blanco, con la promesa de sacrificarlo en su honor. El rey Minos desobedece y conserva al animal con vida, y el dios marino castiga a Minos haciendo que la reina Pasífae se enamore del toro blanco.

Desde el lugar en que se hallaba, Pasífae contemplaba la increíble escena, atrapada también por el prodigioso escenario sobre el que Minos, su esposo, estaba siendo proclamado rey de Creta por designio de los dioses. La futura reina examinó entonces el cuerpo del toro, admiro sus miembros, 
sus esculturales músculos, sus ojos profundos. Un extraño e inesperado cosquilleo recorrió sus muslos y sin poder evitarlo, entorno los labios y se los humedeció levemente con la lengua. (Souvirón, 2017, P. 24).

En la tragedia griega, una de las constantes que se repiten en la trama, es el cumplimiento del destino. Sus personajes no pueden salirse del designio de los dioses. Un ejemplo es la tragedia "Edipo rey" de Sófocles, en donde el parricidio y el incesto flotan en una atmósfera trágica inclusive antes de los acontecimientos. En el caso específico del mito del minotauro, prevalece la idea de venganza y la ira implacable que reside en el alma de Poseidón sobre el rey Minos, aunque la acción trágica recae sobre la reina Pasífae:

- ¿Cómo conseguidas que el toro se encele? Preguntó la reina.

Dédalo, que había comprendido las intenciones de la mujer, se atrevió a decir:

- Poderosa Pasífae, ¿estás segura de lo que pretendes hacer? Bien sé que no puedo interferir en los designios de una reina, pero, como leal servidor de su casa, debo intentar disuadirte. Algún dios te está empujando a llevar a cabo un acto irreparable. Ella endureció su rostro y respondió:

- En efecto, no debes interferir. Y si, como dices, un dios me está empujando, ¿cómo podría evitarlo? Responde a mi pregunta. (Souvirón, 2017, P. 35).

En el anterior diálogo entre Dédalo y la esposa de Minos, notamos que la reina Pasífae, quien mueve los hilos de la trama, es víctima de la desventura y la fatalidad; es víctima de la venganza de Poseidón, y por lo tanto, también se pone en escena la inexplicable desgracia de los habitantes de Cnosos frente al designio de los dioses; en síntesis, por encima de la voluntad humana están los preceptos de los inmortales.

Desde el punto de vista de la relación de semejanza entre los símbolos; las creencias y los sucesos dentro de la trama del minotauro; tanto Ovidio, como Plutarco y Apolodoro han visto todo un sistema de símbolos de la sociedad cretense. En los rituales en honor a la luna (Pasífae) las danzas no solamente era un espectáculo, sino que mediante el ritmo y el trance; los dancentes entraban en comunión con los dioses, la naturaleza y las fuerzas oscuras de la muerte; suprimiendo así las fronteras entre los dioses y los 
hombres. Durante este rito lunar la reina Pasífae utilizaba cuernos de vaca y el peplo con figuras de animales; mientras que el rey Minos observaba el ritual cubierto con una máscara del toro. Desde este punto de vista simbólico, Pasífae representa al universo y el rey representa al poder sin límites.

En el siglo XXI el desarrollo del psicoanálisis ha sido fructífero, a tal extremo que su función ha traspasado las fronteras de la psicología para abarcar otros campos como la sociología, la pedagogía, la biología; llegando inclusive a la pintura a través de la psicología del arte. Desde la óptica del psicoanálisis la fecundación de la reina Pasífae por el toro blanco y el nacimiento del minotauro no es, sino la expresión de ciertas formas de desviación del instinto sexual con respecto a la fecundación biológica cuya finalidad es la procreación normal y natural, por lo tanto, desde la visión del psicoanálisis encontramos una perversión que transgrede la realidad psíquica de la moral; asimismo, si el instinto del inconsciente se sobrepone a los códigos del consciente o del super yo, las consecuencias son graves; pues de las uniones prohibidas sólo pueden nacer monstruos, es decir, el placer perverso unido a la satisfacción pulsional sólo trangrede las reglas de la cultura.

Figura 4. John Vanderlyn - Ariadna durmiendo en naxos 1812 (122)

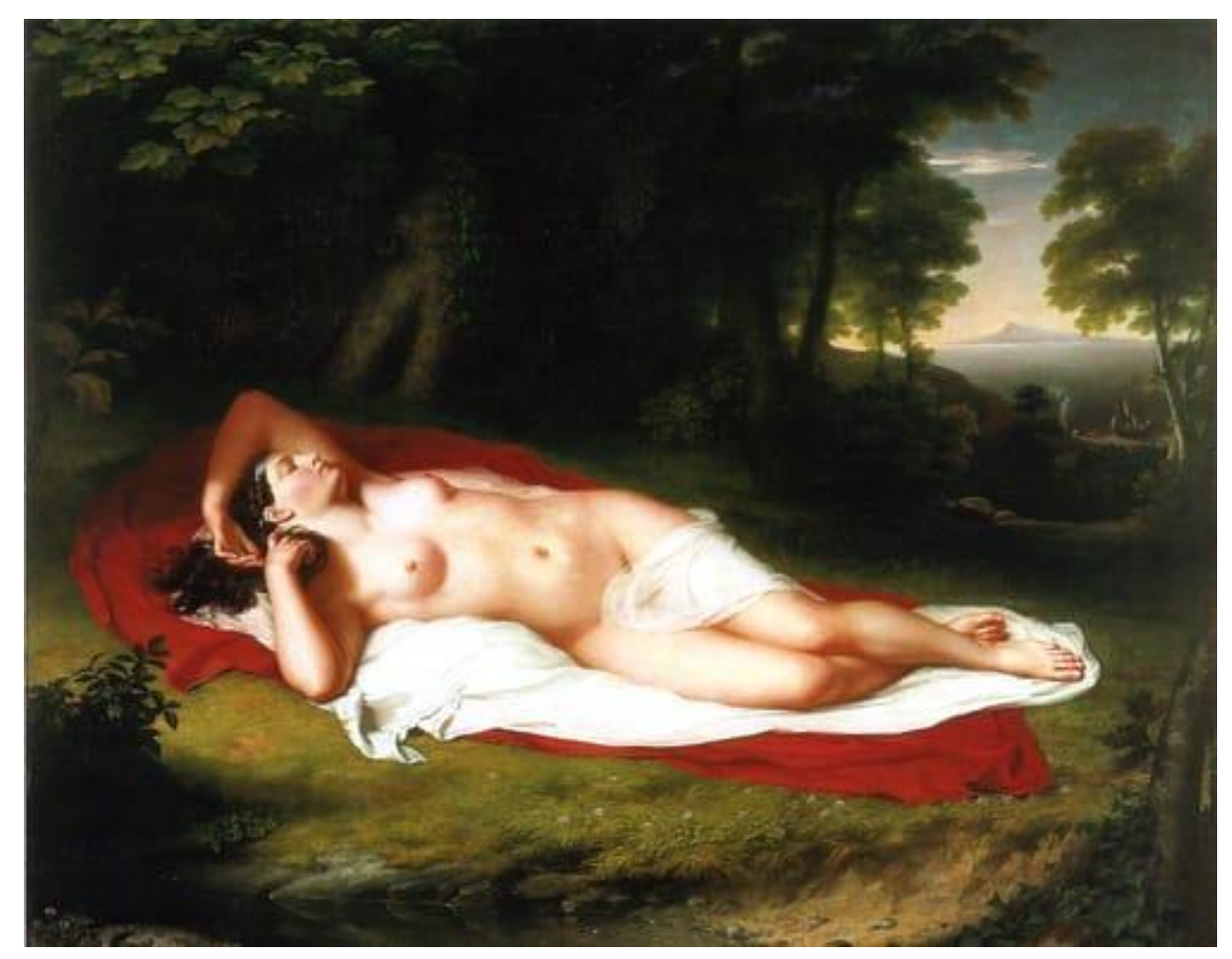

Nota. $174 \times 221 \mathrm{~cm}$. Academia de bellas artes Pensilvania 
Un personaje clave en la trama del laberinto del minotauro es la princesa Ariadna, hija del rey Minos y la reina Pasífae; es importante porque ella es el artífice de la muerte del minotauro, pero es a la vez la víctima de los tormentos del amor y sus consecuencias trágicas. Si analizamos las formas en que se manifiesta el amor según Platón, tenemos que la reina Pasífae está en el plano del instinto erótico en su forma más primitiva y perversa; en cambio Ariadna está en el plano del enamoramiento, en donde el amor nace de la contemplación física de la persona:

El rey lo miraba con recelo, hurgando una y otra vez en el abismo de su memoria en busca del lugar o el momento en que no había visto antes. Detrás del soberano, sobre un asiento de madera labrada, una muchacha contemplaba absorta al desafiante extranjero. No podía apartar la vista de su rostro; percibía su determinación, su fuerza, su audacia; admiraba sus piernas abiertas, que apoyaba en el suelo semejante a un coloso, sus brazos fuertes como árboles, sus ojos profundos, y su torso erguido en aquel estrado como un roble en medio de un desierto. Era Ariadna, hija de Minos (Souvirón, 2017, P. 68).

Decimos que la princesa Ariadna es el artífice de la muerte del minotauro, porque desde su primer encuentro, con el príncipe Teseo, en su imaginación, en sus sueños y en sus febriles delirios, estaba naciendo ya, el instinto erótico en las profundidades de su inconsciente. Al descubrir la verdadera naturaleza de sus sentimientos, la princesa comienza a hilar un ovillo divino, tan fuerte capaz de lacerar el cuerpo del minotauro y darle muerte.

Repentinamente se derrumbó en medio de un sordo estertor. Teseo se levantó y vio el hilo enredado en sus pies; el hilo de Ariadna lo había derribado. El minotauro rugía, Tensaba el hilo para romperlo y liberarse de él, pero estaba muy enredado y a cada intento se enmarañaba más. Sacudiéndose rabioso, sólo conseguía que el hilo penetrara en su carne, hundiéndose en sus tejidos como un cuchillo en un pedazo de queso. Teseo se incorporó, vio la tensión del hilo, sabía que si se rompía estaba condenado a una muerte lenta y cruel. No podía perder tiempo. Se lanzó sobre el monstruo. (Souvirón 2017, P. 84).

Una vez que ha matado al monstruo, Teseo salió del oscuro laberinto exhausto y manchado de sangre. Ariadna movido por el intenso amor lo abrazo apasionadamente y 
condujo a los atenienses a sus naves. Semanas después de haber navegado por las profundidades del mar y después de haber vencido las violentas tempestades, desembarcaron en la isla de Naxos, donde Teseo abandonó a Ariadna y se enrumbó a Atenas. En Naxos la princesa Ariadna vivió durante años, en medio de la melancolía, la tristeza y la desventura, porque Teseo mató al minotauro gracias a su ayuda, pero no cumplió con sus promesas de amor.

La desventura de Ariadna es semejante a la melancolía que padece la sacerdotisa de Hécate, quien poseía todos los conocimientos del mundo celestial y subterráneo. Jasón Comandante de los Argonautas; juro por todos los dioses del Olimpo que sería fiel a Medea, siempre y cuando le ayudara a conseguir el vellocino de oro; custodiado por el dragón hijo de Tifón. Conseguido el objetivo y ya en el reino de corinto, Jasón se casó con Creusa hija del rey Creonte, olvidando así su promesa de amor y fidelidad.

Desgraciada de mí, que me he convertido en la mujer más desdichada de la tierra-aullaba-ojalá Jasón hubiera muerto, yo lloraría, con razón, la pérdida de un esposo querido. Mis hijos serían ahora huérfanos y no los hijos de un traidor. (Barceló, 2017, P. 42).

La desdicha de Medea al seguir a Jasón en su huida, no sólo radica en la renuncia a Colquide de su reino, sino también se convierte en fratricida al descuartizar a su Hermano Apsirto. De la misma manera Ariadna, al huir con Teseo no sólo traicionó a su reino Cnosos, sino que ella es cómplice también de la muerte de su hermanastro Asterión a manos de Teseo.

¿Cuál es el impulso o pulsión que ha llevado a la melancolía y a la desventura tanto a Medea como a Ariadna? Eurípides, uno de los grandes exponentes de la tragedia griega; sostiene que la grandeza y la miseria, la felicidad y la desgracia del hombre radica en el doble carácter de Eros, cuya fuerza puede llevar al hombre al odio más intenso pero también a la plenitud del ser. Esta fuerza perniciosa de Eros es concebida mejor por Antígona en la tragedia de Sófocles:

¡Amor invencible en la pelea! Amor que en el corazón te infundes, que en las tiernas mejillas de las muchachas te posas y posas al otro lado del mar y frecuentas las rústicas cabañas. De ti no se libra nadie entre los inmortales, ni entre los efímeros hombres; y quién te recibe, se enfurece. Tú de los hombres justos arrancas injustas determinaciones, para 
arruinarlos; y también tú has concitado la rencilla en esta familia. (Sófocles, 1989, P. 328).

Uno de los filósofos que mejor ha teorizado sobre la naturaleza del amor es Platón. En el banquete o dialéctica del amor, a través de la conversación que tienen Sócrates, Apolodoro, Pausanias y Eriximaco, observamos que la naturaleza de la atracción sexual se remonta al mito de la androginia; hombres esféricos dotados de doble sexo, cuatro brazos y cuatro piernas, que eran el símbolo de la armonía y de la felicidad.

Eran tres los sexos y de tales características por la siguiente razón: lo masculino era en un principio descendiente del sol, lo femenino de la tierra y lo que participaba de ambos de la luna, porque también la luna participaba de lo uno y de lo otro. Y precisamente eran circulares ellos mismos y su manera de avanzar por ser semejantes a sus progenitores. Eran, pues, terribles por su fuerza y su vigor y tenían gran arrogancia, hasta el punto de que atentaron contra los dioses. Entonces Zeus y los demás dioses deliberaron lo que debían hacer con ellos. Tras mucho pensarlo, al fin Zeus dijo: Me parece que tengo una estratagema para que continúe habiendo hombres y dejen de ser insolentes, al hacerse más débiles. Ahora mismo, voy a cortarlos en dos a cada uno. (Platón, 1989, P. 67). 


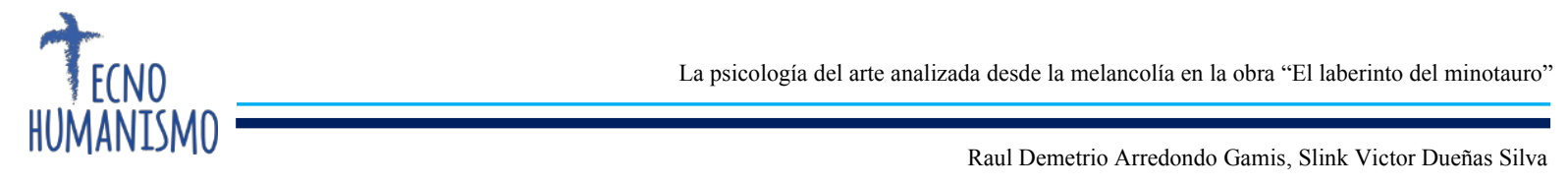

Figura 5. Ariadna y Teseo (123)

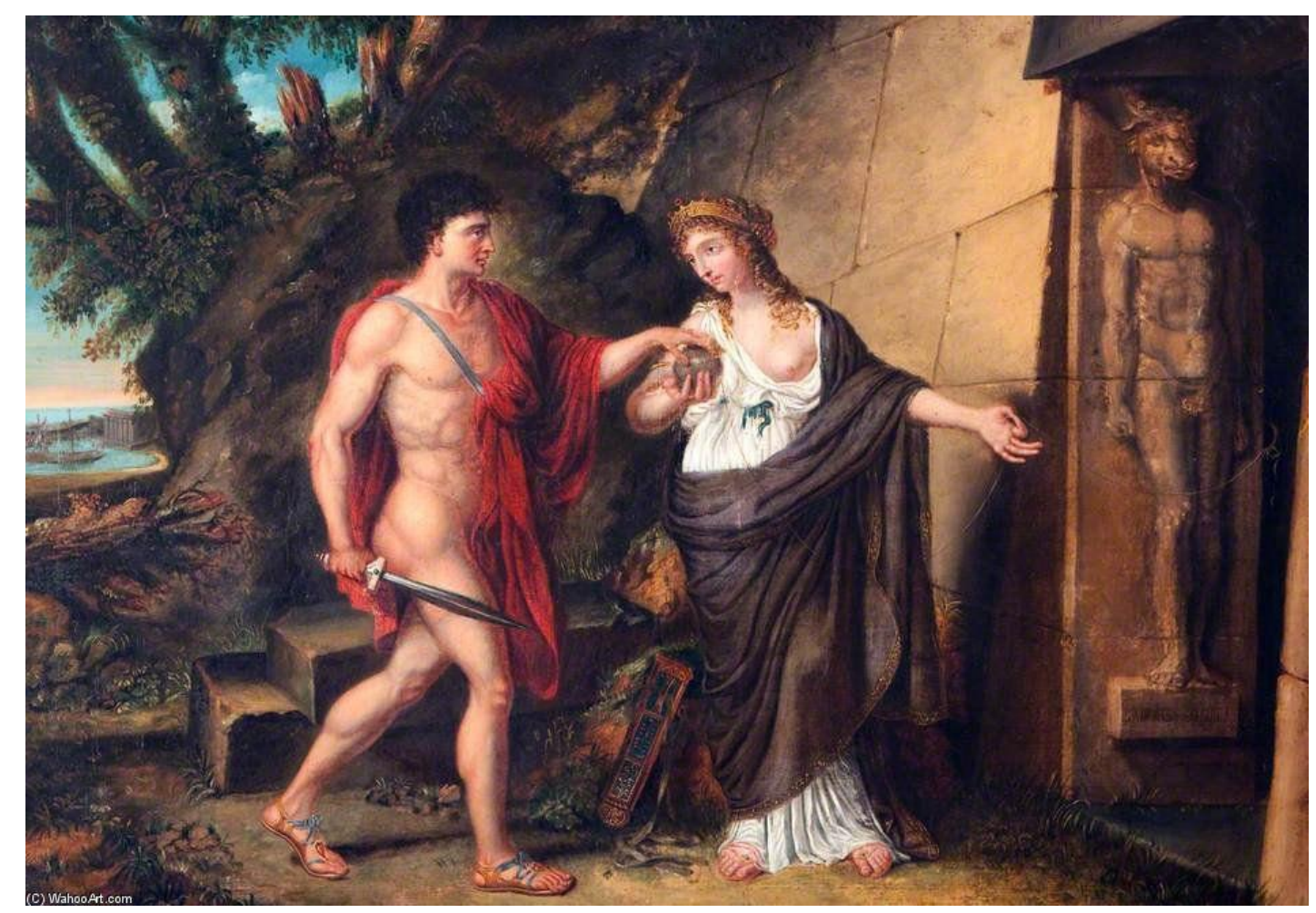

El mito de la androginia de Platón es una excelente explicación de la naturaleza de la atracción erótica y sus consecuencias, una explicación del porqué sentimos cierta nostalgia, cierta melancolía cuando nos separamos del ser amado. El mito de la androginia es una descripción del sentido oscuro y doloroso que caracteriza las desventuras de Ariadna y de Medea.

En el héroe y vencedor del minotauro en creta, también encontramos en su personalidad ciertos rasgos de melancolía. Este estado de ánimo se conoce en el campo de la psicología clínica como depresión. Este síndrome psiquiátrico está relacionado con algunos estados neuróticos y perturbaciones de tipo psicosomático. Estos estados de empobrecimiento afectivo se manifiestan en Teseo como un sentimiento de duelo y autoacusación por la muerte de su padre Egeo rey de Atenas.

Había conquistado territorios nuevos, había organizado juegos atléticos en el istmo de Corinto, y delimitado las fronteras entre la región del Ática y la del Peloponeso y, sin embargo, lejos de sentirse satisfecho, notaba que cada día, cada noche, el dolor lo acompañaba como un parasito adherido al alma. Entre el estruendo del mar oriental, que ahora llevaba el nombre de su padre, Egeo, y el húmedo telar que tejían a su alrededor las 
salpicaduras de las olas, Teseo el triunfador se sentía, solo, desamparado.

(Souvirón, 2017, P. 10).

La palabra melancolía, etimológicamente proviene de dos voces griegas (Melasnegros y xolias-humor) y está relacionado con la bilis negra. La melancolía desde sus inicios siempre estuvo asociada a la tristeza, la angustia y la ansiedad. Desde el punto del psicoanálisis está relacionada con los neurotransmisores y el desequilibrio de las sustancias químicas que se encuentran en el cerebro.

Uno de los intelectuales que mejor ha estudiado la melancolía como proceso mental es el inglés Robert Burton en su libro "Anatomía de la melancolía". En este tratado Burton sostiene que en la melancolía intervienen muchos factores, como los genes, la falta de afecto y el contexto social, es decir, que la melancolía es consecuencia de factores ontogenéticos y filogenéticos.

Si se aplica esta teoría de Burton, en el análisis de la personalidad del héroe Teseo en "El laberinto del minotauro" de Ricardo Córdova, tenemos que una de las causas por el cual sufre de melancolía Teseo; es el abandono que padece durante la infancia por parte de su padre Egeo. Este sentimiento de tristeza, este vacío, esta desesperanza que siente Teseo, se va a manifestar no en la niñez sino en la juventud.

El nacimiento del príncipe Teseo es paradógico, porque Egeo rey de Atenas no podía tener hijos en sus dos esposas, Mélite y Calciópe, atribuyendo estos hechos a la ira de Afrodita, sin embargo, Medea le prometió procurarle un hijo mediante el uso de la magia, siempre y cuando Egeo la protegiera de la venganza de Creonte rey de Corinto. Medea mediante un hechizo emborracho a Egeo e hizo que embarazara a Etra princesa de Trecén. De esta unión mágica nació Teseo y fue abandonado por Egeo en el reino de Trecén. Esta ausencia del padre va a provocar que Teseo una crisis emocional tipo melancólico.

En la mitología griega, la melancolía era considerada como un síntoma de delirio, por eso Ayax trastornado por la locura se lanzó sobre un rebaño de ovejas, creyendo saciar su sed de venganza; cuando recobró el juicio se vio cubierto de ignominia y decidió suicidarse. Acontecimiento semejante le sucedió al gran héroe Heracles que cegado por la ira de Hera, quedo enloquecido y mato a sus hijos y los arrojó al fuego. Por haber matado al minotauro y por haber liberado a los atenienses de la siniestra ofrenda, Teseo fue considerado héroe nacional para los griegos, independientemente de este acto heroico, 
en la mente de Teseo siempre estuvo como una sombra su nacimiento oscuro, porque él nunca supo si era el hijo del dios Poseidón o del rey Egeo. Asimismo, su melancolía provenía; por la locura de su padre, quien enloquecido se precipito al vacío.

Desde lo alto del cabo, el viejo Egeo observaba el barco que navegaba a toda vela, dejando a su popa una estela blanca que contrastaba con el color de la enorme vela negra. Las lágrimas inundaron sus ojos a la vez que comprendía la magnitud de su fracaso: había perdido a su hijo, no había conseguido liberar del vergonzante tributo a su ciudad. Se incorporó lentamente, temblando de miedo, vencido por el dolor, y antes de que nadie pudiera detenerlo, dio unos pasos tambaleantes hacia el abismo del acantilado y, con la mirada fija en la fatídica vela que anunciaba la muerte de su hijo; se lanzó al vacío deseando acabar con un dolor que ya no sentía capaz de soportar. (Souvirón, 2017, P. 102).

Figura 6. El laberinto del minotauro - 124

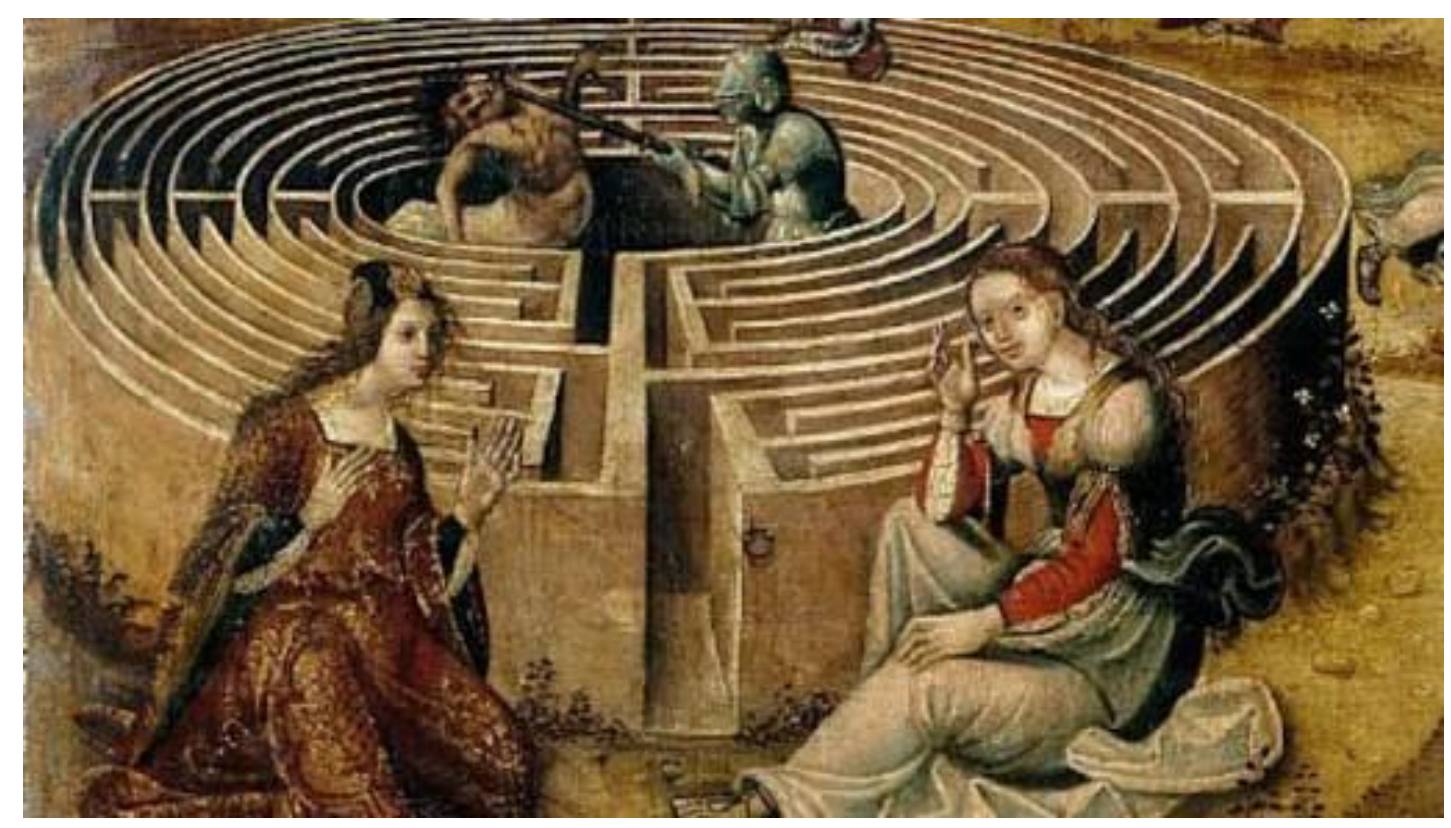

En la interpretación o hermenéutica de una obra, siempre nos encontramos frente a un objeto de estudio (la obra de arte) sobre la cual centramos nuestra atención, lo ubicamos, lo observamos y lo analizamos desde diferentes perspectivas, tal es así, que podemos hablar de tres aspectos: de las relaciones entre el objeto de estudio y el autor, de los vínculos entre el objeto de estudio y el contenido y finalmente de los lazos entre el objeto de estudio y el decodificador. El objeto de estudio de nuestra investigación en esta 
parte de "El laberinto un del minotauro" de Ricardo Córdova; se centra en el contenido o en las significaciones del "laberinto".

Uno de los escritores latinoamericanos que mejor ha interpretado el laberinto del Minotauro es Jorge Luis Borges, en su relato corto denominado "La casa de Asterión". Este cuento forma parte del libro "El Aleph" conformado por diecisiete relatos. Cada sexto narrativo no se enfrenta a un mundo extraño en los que pareciera borrarse de los límites de la realidad y sólo prevaleciera el caos.

Jorge Luis Borges en "La casa de Asterión” utiliza un lenguaje metafórico, aforístico y sobre todo alegórico, para describir y analizar datos reales históricos y el mito. También encontramos en este cuento temas tan complejos, como el caos, la soledad del minotauro y la muerte.

Es verdad que no salgo de mi casa, pero también es verdad que sus puertas (cuyo número es infinito) están abiertas día y noche a los hombres y también a los animales. Que entre el que quiera. No hallará pompas mujeriles aquí ni el bizarro aparato de los palacios, pero si la quietud y la soledad. (Borges, 1974, P. 569).

En el anterior fragmento, cuando Asterión habla de soledad, no sólo se refiere al silencio que hay en el recinto; sino a su propia melancolía. Desde el punto de vista del psicoanálisis, se ha demostrado observacional y experimentalmente la importancia de los cambios emocionales y el papel que desempeña la comunicación como interacción entre los seres humanos. Cuando las relaciones afectivas-comunicativas no pueden establecerse normalmente, entonces, aparecen las perturbaciones de orden psicosomático que traen como consecuencia la melancolía y la depresión.

Desde nuestra postura de observadores acuciosos, notamos que el relato "La casa de Asterión" nos ubicada frente a dos contextos diferentes. Por una parte, nos sitúa frente a lo real y concreto, y por otra parte nos ubica frente a una realidad ficcional, que en la temática de Borges pareciera una realidad en conformidad con lo real, sin embargo, son parte ilusoria de un sueño. Es en esta conjunción en donde Asterión se atarea en su lucha casi humana, pretendiendo ser libre y salir airoso siempre de sus contiendas, pero al final descubrirá que su existencia era ilusoria, predestinada y conducida por alguien y que su destino se cumplirá indefectiblemente. 
Desde entonces no me duele la soledad, porque sé que vive mi redentor y al fin se levantará sobre el polvo. Si mi oido alcanzara todo los rumores del mundo, yo percibiría sus pasos. Ojalá me lleve a un lugar con menos galerías y menos puertas. ¿Cómo será mi redentor?, me pregunto. ¿Será un toro o un hombre? ¿Será talvez un toro con cara de hombre? ¿Ho será como yo? (Borges, 1974, P. 570).

El anterior monólogo, sólo puede reflejar la melancolía y el mundo incierto en que vive Asterión, un mundo sin formas, un mundo de laberintos irregulares, con la única esperanza que llegue su Salvador, la muerte. Esta prisión compleja de calles cruzados y construcciones infinitas, fue obra del arquitecto Dédalo, bajo el reinado del monarca Minos, para contener la furia de Asterión, sin pensar que esta lúgubre prisión también sería el recinto y prisión de Dédalo y su hijo Ícaro.

Al asistir sobre el carácter esencialmente psicoanalítico de la obra "El laberinto del minotauro" de Ricardo Córdova, se infiere que "el laberinto" no es sino una metáfora, que oculta la represión, un mecanismo severo y cruel que sirve para ocultar el deseo del inconsciente. Asimismo, el Minotauro, el ser que está encerrado en el oscuro laberinto es la encarnación del deseo irracional y el héroe Teseo es el ideal de la un moral del yo. 
Figura 7. El rey Minos - 125

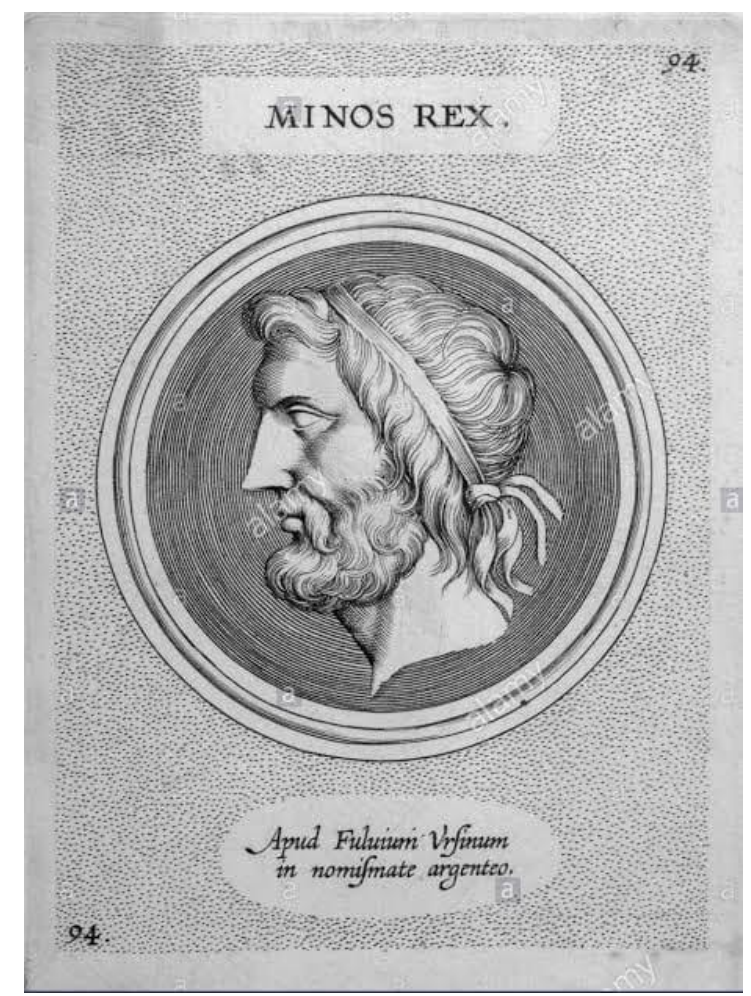

El último personaje dentro de la trama del "laberinto del minotauro" de Ricardo Córdoba, es el rey Minos, un personaje ambivalente que siempre estuvo entre los hilos de la neurosis obsesiva, la melancolía y la manía de hybris. No sabemos con certeza su origen, porque el historiador y Diodoro lo considera como hijo del rey Zeus y de la bella Europa, sin embargo, el vate Pausanias lo considera hijo de la ninfa Ida y del rey Licasto.

Desde una mirada psicoanalítica, la melancolía está situada en el contexto de los estados afectivos, y se ve expresado como dice el mismo Freud "como una caída de los lazos con los objetos de la líbido”. Este estado de decamientos y suspensión del sentido de la vida se manifiesta en el rey Minos por la muerte de su hijo Androgeo:

Androgeo visitó Atenas y ganó todas las competiciones en los juegos Panateos. Pero el rey Egeo sabía de su amistad con los cincuenta hijos rebeldes de Palas y temiendo que pudiera convencer a su padre Minos de que los apoyara en una revuelta, organizó una conspiración con los megarenses para tenderle una emboscada en Énoe, de camino a Atenas, donde iba a participar en unos juegos fúnebres. Androgeo se defendió con valentía, pero resultó muerto en la fiera pelea. (Graves, 1985, P. 407). 
Afirmamos que el rey Minos tiene un temperamento melancólico ambivalente, porque después de la muerte de su hijo Androgeo, su estado emocional es cambiante y fluctúa siempre entre la tristeza y el odio. Este cambio brusco e intempestivo del estado de ánimo lo podemos enmarcar dentro de la neurosis obsesiva melancólica. De igual manera, el rey Minos sufre de delirios de hybris (transtorno paranoide que genera un ego desmedido) porque no solamente es un cruel tirano que demanda como tributo de jóvenes atenienses para alimentar al Minotauro; sino que destierra a sus hermanos Radamantis y Sarpedón cuando muere el rey Asterión, es decir, que en Minos predomina el impulso irracional y desequilibrado del poder sobre mortales e inmortales; desafiando inclusive al rey de los mares Poseidón. Una muestra de esta patología de hybris, lo encontramos en un pasaje de la obra teatral de Julio Cortazar denominado los reyes:

- Minos. Minotauro, silencio en acecho, signo de mi poder sobre la concavidad del mar y sus ramos de azules islas. Testimonio vivo de mi fuerza, del fillo abominable de la doble hacha. ¡Sí preso y condenado para siempre! (Cortazar, 1970, P. 11).

David Owen en su obra "En el poder y en la enfermedad” propone que el síndrome de hybris es consecuencia de la ambición por el poder. Este síndrome en el caso de Minos lo enloquece, dándole la convicción de que los dioses cumplirán sus deseos y que el trono le pertenece por designio divino y no por mandato humano.

\section{Conclusiones}

"El laberinto del minotauro" de Ricardo Córdova; es una alegoría a la melancolía y a la imposibilidad de encontrar la libertad plena. El pintor recrea el mito griego del minotauro, pero desde una visión del arte moderno. Bajo la luz de la teoría psicoanalítica los personajes que rodean a Asterión, no sólo reflejan ciertos estados de melancolía como producto del desencanto con la realidad, sino reflejan sobre todo algunas estructuras oscuras del inconsciente del ser humano.

Córdova es un pintor que tiene el temperamento melancólico innato. La belleza de su obra no es puramente formal, sino es fruto de su mundo interior, de su identidad y de sus sentimientos. La pintura de Córdova es una alegoría a la melancolía, una tristeza que refleja el mundo del artista y que se exterioriza de forma silenciosa en su arte.

\section{Referencias bibliográficas}


Barceló. (2017). La ira de Medea. España: RBA. Editorial.

Borges, J. (1974). La casa de Asterión. https://www.actorsstudio.org/web/images/pdf/jorge_luis_borges_la_casa_de_asterion.pdf

Cortazar, J. (1970). Los reyes. Buenos Aires: Editorial sudamericana.

Ferraté, J. (1968). Líricos griegos arcaicos. Barcelona: Editorial seix Barral, S.A.

Freud, S. (1996). Obras completas. Madrid: Biblioteca nueva. S.A.

Graves, R. (1985). Los Mitos Griegos. Madrid: Alianza editorial, S.A.

Platón. (1989). El banquete. Madrid: Alianza Editorial. S.A.

Quevedo, M. (2018). El cerebro inconsciente: Los automatismos de nuestra mente. EMSE EDAPP, S.L.

Sófocles. (1989). Tragedias. Madrid: Editorial EDAF. S.A.

Souviron, B. (2017). El laberinto del minotauro. México: RBA Editores.

Xiol, J. (2015). Descartes un filósofo más allá de la duda. España: Edición Batiscafo, S.L. 